\title{
The Effect of Corporate Social Responsibility on Financial Performance with Real Manipulation as a Moderating Variable
}

\author{
Rahmawati \\ Setyaningtyas Honggowati \\ Edy Supriyono
}

Lccounting Dept., Economics ind Business Facullty, Sebehs Nliret Iniversity, Indonesiat

\begin{abstract}
This study aimed to obtain empirical evidence about the effect of real manipulation practices on Corporate Social Responsibility (CSR), and further examined the impact of real manipulation on relationship between CSR and the financial performance of companies in the future. 27 companies listed on Indonesian Stock Exchange during the years 2006-2008 were selected as sample for this study. Data were collected by purposive sampling method and statistical method used for analysis was ordinary least square regression. The study provided empirical evidence that companies engaged in the practice of real manipulation had no influence on CSR activities. The results showed that the higher level of real manipulation on operation cash flow leads to negative effect on the relationship between CSR and financial performance.

Keywords: Corporate Social Responsibility (CSR), real manipulation, corporate financial performance, manufacturing company, Indonesia

JEL: M14, G39, 016
\end{abstract}

Accounting standards established by The Association of Indonesian Accountants allow management to choose a set of policy in applying accounting methods to convey information about the company's performance to external parties. Thus, it provides an opportunity for managers to exhibit opportunistic behavior and efficient contract. That is, the rational manager will choose accounting policies in accordance with their interests. In other words, managers select accounting policies that maximizes their expected utility and or market value of the company. Opportunistic behavior and the efficient contract, encourages managers to

Manuscript received January 28, 2014; revised April 25, 2014; accepted May 16 , 2014.

Corresponding author: rahmaw2005@yahoo.com perform earnings management.

According to Scott (2011: 344) earnings management is the selection of accounting policies by managers of the Financial Accounting Standards which exist naturally and can maximize their utility and/or the market value of the company. Earnings management by Mulford and Comiskey (2002) is the financial numbers game made through creative accounting as a result of looseness flexibility principles issued by GAAP (General Accepted Accounting Principles). In fact, earnings management is managers' intervention in the external financial reporting process in order to achieve a certain level of profit with the purpose to benefit themselves as well as their own company (Saputro and Setiawati, 2004) 
International Journal of Management, Economics and Social Sciences

Motivation to earnings management above indicates explicitly deliberate earnings management practices by managers, which in turn brings negative consequences for shareholders, employees, communities where company operates, career of people, and reputation of managers (Zahra, Priem and Rasheed, 2005). One of the most fatal consequences of manipulating company's earnings by managers result in loss of support from company's stakeholders because stakeholders will face severe problems due to the pressure come from investors, sanctions from regulators, high turnover, possible boycott from activists, and negative news about the company by media (Prior et al., 2008). This action reflects dissatisfaction of stakeholders on the performance of company that manipulate, and finally damage company' $s$ reputation in the capital markets (Fombrun, Gardber and Barnett, 2000).

After reporting unsatisfactory performance of the company, managers use a strategy of selfdefense (entrenchment strategy) to anticipate stakeholders' dissatisfaction. Managers' self defense strategies aim to maintain company's reputation and protect managers' personal career. Among other ways, one way that managers use to perform self-defense is issuing a policy on the application of the company's Corporate Social Responsibility (CSR). CSR deals with ethical and moral issues regarding the policies and behavior of decision makers, such as placing a complex issue to secure the preservation of the environment, human resource management, health and safety, relationships with local communities, and establishment of harmonious relationships with suppliers and customers (Castelo and Lima, 2006). Disclosure of information about the company' $s$ social responsibility helps in building a positive image of company among stakeholders (Orlitzky, Schmidt and Rynes, 2003). This positive image can help companies to establish community ties and build their reputation in the capital markets, because it can improve their ability to negotiate attractive contracts with suppliers and governments, set premium prices for goods and services, and reduce the cost of capital (Fombrun et al., 2000). Similarly, Castelo and Lima (2006) explain that by adopting CSR practices, companies can generate more favorable regulatory treatments, support of social activist groups, the legitimacy of the industrial community, positive news from media, and ultimately the company's reputation remains well preserved.

The context of this research problem is the suspicion that managers use CSR mechanism as a powerful tool for self-defense when they do things harmful for the interests of shareholders or stakeholders. According to Cespa and Cestone (2007), management has the incentive to manipulate earnings to project socially-friendly image through CSR activities to gain support from stakeholders. With this tactic, the manager will reduce the possibility of getting pressure from dissatisfied shareholders, or other stakeholders affected by the practice of earnings management. Furthermore, Prior et al. (2008) report that there is a disagreement between the effect of earnings management and CSR, which in turn will impact on the company's financial 


\section{Rahmawati et al.}

performance. However, companies that implement CSR programs must reserve adequate financial resources, which will affect the company's financial performance in the long term. This phenomenon encourages academicians to conduct research to describe the influence of earnings management on CSR, and subsequently investigate the impact of these relationships (earnings management and CSR) on corporate financial performance.

Research on the relationship of CSR and corporate performance is required because previous research showed inconsistent results. Results of research conducted by Dahlia and Siregar (2008) showed that CSR activity proved to have a significant effect on financial performance but does not affect the company's market performance.

The differences of this study as compared to previous studies like Prior et al. (2008) are:

1. This study population is publicly listed manufacturing companies on the Stock Exchange in the duration from 2006 to 2008.

2. Earnings management variable in this study adopts real activities manipulation strategy, the manager prefers to use this strategy because manipulations are difficult to be detected by auditors.

On the basis of this background and previous literature review, the goal to be achieved from this study is to analyze and obtain empirical evidence regarding: (1) the influence of real manipulation practices on CSR activities and (2) the influence of CSR activities on relationship between real manipulation practices to the company's financial performance in the future.

\section{LITERATURE REVIEW}

\section{Positive Accounting Theory}

Positive accounting theory explains why accounting policy became an issue for company and interested parties with financial statements, and to predict accounting policies selected by company under certain conditions (Watts and Zimmerman, 1986). This theory is based on the view that the firm is a ' nexus of contracts' i.e. the company is an estuary for various contracts that came to it. For example, contracts with employees (including managers), suppliers, and financiers. As a collection of various contracts, rational contracting companies want to minimize the costs associated with contracts that go to it, such as boarding negotiation, monitoring contract performance, the possibility of bankruptcy or failure, and others. Some of these contracts involved accounting variables, thus positive accounting theory argues that companies will utilize accounting policies in order to minimize contracting costs. This condition is reinforced by the provision of flexibility by resident entities of management standards to choose from a set of accounting policies permitted. Positive accounting theory becomes an interesting rationale for CSR reporting.

Positive accounting theory used agency theory to explain and predict accounting policy chosen by manager. Positive accounting theory formulated by Watts and Zimmerman (1986) has predicted three hypotheses that encourage companies to undertake earnings management, namely:

1. The bonus plan hypothesis: Manager of a company that had a bonus program 
International Journal of Management, Economics and Social Sciences

associated with accounting figures will tend to choose accounting procedures that shift reported earnings from future period to the current period (increase reported earnings today), ceteris paribus.

2. The debt covenant hypothesis: Company getting closer to breach debt covenants (debt contract) will tend to choose accounting procedures that shift reported earnings from future periods to the current period (increase reported earnings today), ceteris paribus.

3. The political cost hypothesis: The greater the political costs faced by a firm, the managers tend to choose accounting procedures that defer reported earnings from current to future period (lower earnings reported today), ceteris paribus.

\section{Hypotheses Development}

Earnings quality increases with strict accounting standards, which limits the accrual earnings management, but there are some consequences that may be more beneficial. First, managers increase real activity manipulation (more expensive due to higher earnings quality increases additional benefits). Second, more stringent accounting standards could increase profits by accruals. Earnings management through real activities can be detected through cash flow from operations, discretionary expenses, and production costs. Research on earnings management through real activities just concentrates on investing activities as a reduction of research and development expenditure (Roychowdury, 2006).
Roychowdury (2006) provides evidence that managers manipulate through real activities by providing rebates to increase sales, reduce boarding goods sold through increased inventory, and reduce discretionary expenses to increase reported earnings. Several studies have been conducted on earnings management by focusing on investment and research and development expenditures. Dechow and Sloan (1996) found that managers reduce the cost of research and development at the end of the period to boost short-term profits. Similarly, Bushee (1998) finds evidence consistent with reduced research and development costs to increase profits.

Graham et al. (2005) discover in their study that financial executives indicate a willingness to manipulate earnings through real activities rather than accrual. There are two reasons to manipulate earnings through real activities, i.e. (1) manipulation of accruals may draw the attention of the auditor or regulator to examine more deeply than the real decisions on prices and production, (2) manipulation of accruals are risky in nature.

Roychowdury (2006) indicated that earnings management through real activities manipulation is a transfer of income from the management of normal operating practice to practice abnormal operation, performed by the managers to deceive some stakeholders. He believes that the financial statements should be made on the basis of normal operation. Displacement of normal operating practice to not normal operation practice does not contribute to firm value even though managers achieve reporting objectives. Managers involved in earnings management are 


\section{Rahmawati et al.}

concerned with personal gain to achieve reporting objectives because they act as agents, e.g. earnings management to avoid losses, and avoid debt covenant violations, to avoid government intervention, as well as to increase the bonus.

In Indonesia, research on manipulation of real activities was conducted before by Andayani (2008). The result of research showed that manufacturing companies were doing overproduction, discounts, allowances, and credits as an indication of earnings management, which leads to high production costs.

We know that accounting data is used to help, monitor, and regulate the contractual relationship among a company's stakeholders. Explicit and implicit compensation contracts are used to limit the incentives of management and external stakeholders. Loan contracts need to be written down in order to prevent the management to take action that can lose position of creditors. Such contracts often use accounting numbers as a measure of corporate performance as stated in the contract agreement. Real activities manipulation is an important concern of research lately because managers can do it at any time during the current accounting period. Some techniques that can be performed in the manipulation of real activities include sales management, excessive production, and reduction in discretionary spending.

Nevertheless, the impact of real manipulation affects not only owners, but it has also a strong influence on other stakeholders. Stakeholders are a group of people who have a risk as a result of their investment in the form of capital, human resources, or something of value in a company
(Clarkson, 1994). Under this definition, management actions such as the practice of real manipulation would mislead stakeholders on asset valuation, transactions, and financial position, which have serious consequences to shareholders, creditors, employees, and society as a whole (Zahra et al., 2005).

Through CSR activities, managers have different goals: to increase company' s positive image through media reports, the legitimacy of local communities, and regulations that make it easier and get less criticism from investors and workers. At the same time, some activities can reduce the possibility of a boycott of the company's products, and avoid lobbying against the company. Managers believe that by satisfying the interests of stakeholders and planning to increase the positive image by taking responsibility in social and environmental issues, they could reduce the possibility of being investigated more thoroughly by stakeholders who take pride against real manipulation acts. Some of them abuse the benefits of CSR activities to erase doubts about the efficiency of the implementation of social policies as a mechanism of corporate governance. This view differs from the traditional stakeholder theory in suggesting that stakeholder participation is an important way for the management to take action as follows: (1) strengthen the company's perception of social legitimacy, (2) strengthen the relationship among the board of directors, and (3) binding the management with a higher standard of performance. All these factors can help to improve financial performance (Luoma and Goodstein, 1999). 
International Journal of Management, Economics and Social Sciences

Some researchers suggest that the media has an important influence on Corporate Social Responsibility (CSR) activities. Bansal (2005) reported that increasing media reports raise concern because the company can get attention or censure from the public. The threat of negative media publicity has two consequences of all management practices. First, some publications resulting pressure force the company to a commitment to sustainable development, and threats that can erode the good image of the company to apply a practice that cannot be accepted by the public. Second, CSR stimulates certain stakeholders and government lobbying organizations in order to implement changes in business practices. In cases related to earnings management, several stakeholders associate with specific responses. For example, shareholders and other stakeholders proactively requesting restoration of their responsibility for losses due to earnings management practices (Zahra, 2005). In addition, some companies began to develop inhouse programs and allow whistle-blowing, where workers can express their concern about the issue of prudent accounting and operations without self exposure.

In the same context, managers in companies subjected to the rules of the regulators (regulatory motivations) on earnings management practices; they may work to strengthen the security of their jobs by making the protection and still standing in the job if they do not have the competence and qualifications for the long run of the company. Possible means to protect their jobs (and maintain personal gain) by tying in a series of activities commissioned (broad) which aims to build relationships and gain stakeholder support for companies by societal and environmental activities, called CSR. CSR includes activities that incorporate social aspects into product and manufacturing process, adopting progressive human resource practices, improve the level of environmental friendliness through reprocessing and reduce pollution, continued community purpose organization (McWilliams, Siegel and Wright, 2006).

The second argument that justifies the use of insincere CSR, according to the managers, is the manipulation of earnings relating to the application of self-defense by manager. In this view, for social activists and pressure groups, CSR is a simple self-defense strategy for CEOs, who are under pressure from shareholders whose interests would be damaged. Pagano and Volpin (2005) argue that managers will award stakeholders, such as employees, as a generous social activity in form of a self-defense mechanism to avoid pressure from financial markets through a hostile takeover. For that reason, suspected that when managers act to pursue personal interests to mislead stakeholders about the real value of the assets of companies or financial position, they get permission secretly from other stakeholders to validate some practices. Stakeholders can be persuaded to offer the satisfaction of their specific interests and policies that aim to improve the company's CSR.

Real activities manipulation can reduce the value of the company, this action increases the current period income which can have a negative effect on cash flow of next period 


\section{Rahmawati et al.}

(Roychowdhury, 2006). For instance, aggressive price cuts to boost sales volume and achieving short-term profits can lead to the same customers who expect discounts in future periods. This may have implications for the low margins on future sales. Over production generates excess inventory available for sale in a later period and increase the cost of inventory. Manipulation operations activities such as R\&D, production, and capital investment lead to deviations from normal business practices and potentially lower the performance in subsequent years (Roychowdhury, 2006). Therefore, abnormally low operating cash flow will negatively affect the performance, otherwise, abnormally high operating cash flow will have positive effect on performance, both will ultimately affect the performance of CSR.

The companies involved in real earnings management only to meet earnings benchmarks have a high subsequent performance as compared to companies that are not involved and loss the earnings benchmarks (Gunny, 2010). In this setting, performing earnings management to influence the output of the accounting system is not opportunistic, but consistent with the benefits that will be achieved and better performance in the future. So, the real earnings management, as indicated by the amount of operating cash flow will impact the better performance in the future. Operating cash flow is a resource that can be used to grab opportunities lucrative for business. Therefore, companies that have abnormally high operating cash flow will have high performance. Therefore, based on above literature review, the first hypothesis is:
$\mathrm{H}_{1 \mathrm{a}}$ : The practice of real manipulation on operation cash flow has positive influence on CSR activities.

Real activities manipulation can reduce the long term profitability. When companies change the timing and structure of real business transactions, they deviate from normal operating practices, optimal planning and corporate real disturbing cost (Ewert and Wagenhofer, 2005). The manager will manipulate real activities to meet earnings targets, even though it will lower the value of the company in the long run (Graham et al., 2005). Gunny (2005) investigated the consequences of real earnings management (reduced R\&D and selling expenses, general and administrative, to discount the price to boost sales and profits from the sale of assets recognizes the long-term) of the operating performance in subsequent years. Research results indicate that companies that perform real earnings management significantly decreased the negative effect of cash flow and operating income in the following years.

Gunny (2010) argues that a manager who is interested in increasing revenue for the period would cut investment in R\&D and employee training programs. This cost cutting has no economic consequences in the short term, but in the long-term. So, also in the world of banking, offering low interest rate loans to borrowers, on the other hand offering great prizes as well as high interest rates to customers, and cutting costs to boost short-term profits will result in interest expense and discretionary costs will become high as well as a negative impact on performance. 
International Journal of Management, Economics and Social Sciences

Real earnings management can be done with a variety of real activities, such as the use of affiliate transactions (Thomas et al., 2004), by cutting the cost of research and development, advertising and maintenance, as well as delaying the start of new projects (Graham et al., 2005), through the production excess of goods, discount sales, discretionary expenses, general and administrative expenses (Roychowdhury, 2006), through a set of related transactions (related party transactions) and excessive executive compensation (Saanoun et al. 2013), through tunneling transactions (Luo et al., 2012; Johnson et al., 2000; Bhaumik and Gregoriou, 2009) or propping (Jian and Wong, 2010) relations with firms. These activities could potentially degrade the performance of the company. Based on the above arguments, the following hypotheses were proposed:

$\mathrm{H}_{1 \mathrm{~b}}$ : The practice of real manipulation on discretionary expenses has positive influence on CSR activities.

$\mathrm{H}_{1 \mathrm{c}}$ : The practice of real manipulation on production cost has positive influence on CSR activities.

The second aspect addressed in this research is the impact of CSR on financial performance, spurred by the practice of real manipulation. Instrumental stakeholder theory (Donaldson and Preston, 1995) argues that good management affects positive relationships with key stakeholders (shareholders), which in turn can improve financial performance. The basic assumption underlying this theory is that CSR can be used as a tool for organizations to use resources more effectively (Orlitzky et al., 2003), which then has a positive impact on corporate financial performance. Therefore, the management strategy for relations with stakeholders is an intangible asset that can be viewed as a tool to improve financial performance by using resources according to the theory of the firm (Hillman and Keim, 2001). Similarly, Berman et al. (1999) also found evidence that supports the Hillman and Keim statement, which is called the Good Management Hypothesis. The Good Management Hypothesis was explained by Waddock and Graves (1997) as the position where good stakeholder relationships have a positive influence on financial performance.

There are some arguments about the positive impact of CSR on corporate financial performance. First, the argument that managers who want a higher position, tend to pursue shortterm policy focusing solely on financial results giving birth to long-term burden in social issues (Preston and O'Bannon, 1997). Second, the relationship management among a broad set of stakeholders with the aim of the dispute could lead to violence and consumption of organizational resources that could endanger the company's financial performance (Aupperle, Carroll and Hatfield, 1985). Finally, managers can behave opportunistic against financial losses, following the practice of defense (Jones, 1995) with the aim to satisfy stakeholders as explained earlier.

When companies improve their CSR as a consequence of real manipulation, the positive impact of CSR on corporate financial performance should be reduced significantly. This statement is based on the fact that managers 


\section{Rahmawati et al.}

who take refuge in accounting adjustments tend to over-invest in CSR activities to enhance the company's output with self-defense strategy. The emergence of social license of this strategy is unproductive and wasteful and, is expected to have a negative marginal impact on financial performance. For example, managers may overinvest in complex projects that are running with different stakeholders to satisfy their interests and, at the same time, manage earnings in order to give greater license to stakeholders. Rowley (1997) emphasized that a high level of CSR covers a broad relationship with a group of conflicting stakeholders in order to delay the decision making process within the organization.

The next hypothesis is that managers who perform real manipulation try to involve few stakeholders as a way to validate their actions in order to not get the pressure of other stakeholders. This is referred to as an entrenchment strategy. That method can reduce the flexibility of the company and affect the company's financial condition. Hence, the second hypothesis is:

$\mathrm{H}_{2 \mathrm{a}}$ : The higher the level of real manipulation on operation cash flow, then the negative effect on the relationship between CSR and financial performance of company.

Family company, which is listed on the Milan Stock Exchange Italy, using the capitalized costs of $R \& D$ in order to avoid violation of debt covenants in order to reduce the risk of losing control of the company, maintain the viability and prosperity of the company's long-term, and to protect their reputation in the long-term relationship with lenders (Prencipe et al., 2008).
Research results by Abdolmohammadi et al. (2010) showed that a family of private companies in Norway generally manage earnings by decreasing as compared to non-family private companies to avoid overstate financial performance.

Management of US and the UK based companies are encouraged to reduce the number of earnings that the stock price down and they can buy shares at lower prices (Wright et al., 2006). Some other research also proves that to hide private benefits, insiders often perform earnings management. For example, Healy (1985) conducted a research on bonus schemes, and Crocker and Slemrod (2007) worked on the problem of managerial compensation uncovered these facts. Insiders in the weak CG environments, corporate governance company tend to not report the actual financial condition (misreport) to cover their private benefits (Leuz et al., 2003).

Based on the above literature, according to both agency conflict type I (Jaggi and Tsui, 2007; Prencipe et al., 2008; Abdolmohammadi et al., 2010) and type II (Wright et al., 2006; Healy, 1985; Crocker and Slemrod, 2007; Leuz et al., 2003; Luo et al. 2012), insiders perform earnings management to hide the private benefits they get. Behavior management in managing these earnings could affect the company's performance, such as making investment decisions become less than optimal (McNichols and Stubben, 2008) and can increase the cost of capital (Dechow et al., 1996). This research indicates that earnings management can affect the effectiveness and efficiency of the company, 
International Journal of Management, Economics and Social Sciences

which in turn will affect the performance. Therefore following hypotheses are proposed:

$\mathrm{H}_{2 \mathrm{~b}}$ : The higher the level of real manipulation on discretionary expenses, then the negative effect on the relationship between CSR and financial performance.

$\mathrm{H}_{2 \mathrm{c}}$ : The higher the level of real manipulation on production cost, then the negative effect on the relationship between CSR and financial performance.

\section{METHODOLOGY}

The data used were secondary data in the form of annual financial reports of 27 manufacturing companies, listed on Indonesia Stock Exchange (IDX) during the fiscal period 2006-2008. The sample of this study was taken from several sources: Indonesia Stock Exchange' s website, Galeri Investment of the Economic Faculty in the Sebelas Maret University (UNS), Master of Science Program's database in the Gadjah Mada University, PDBE (Data Center of Business and Economics Faculty of Economics and Business) Gadjah Mada University, and Indonesian Capital Market Directory (ICMD).

The study sample was selected by using a purposive sampling method, including the samples which fit in the following criteria: Manufacturing companies listed on the Stock Exchange that published audited financial statements, which were consistent from the years 2006-2008, presents CSR disclosure in its annual report in Indonesian currency, not a merger, acquisition, and other business changes (divestitures). The total sample used in this study was 27 manufacturing companies in Indonesia.
This study used ordinary least square regression to test the hypothesis. The first hypothesis can be formulated with the model as follows:

$C S R_{i t}=\lambda_{1}+\lambda_{234}(\text { Mar })_{i t}+\lambda_{5}(c f p)_{i t}+\varepsilon^{\prime}{ }_{i t}$

The result of testing the first hypothesis was based on whether the coefficient is positive and significant. These results interpret that the higher level of real manipulation, then the greater CSR activity.

The second hypothesis is tested with the following model:

$$
\begin{aligned}
& C F P_{i t}=\beta_{1}+\beta_{2}\left(\text { Mar }_{i t-1}\right)+\beta_{3}(C S R)_{i t-1}+\beta_{4} \\
& \left(M a *^{*} C S R\right)_{i t-1}+\beta_{5}(S I Z E)_{i t}+\beta_{6}(K O M)_{i t}+\beta_{7}(K P)_{i t} \\
& +\beta_{8}(K I)_{i t}+\beta_{9}(L E V)_{i t-1}+\varepsilon^{\prime}{ }_{i t} \cdots \ldots . . .(2)
\end{aligned}
$$

The second hypothesis, based on the coefficient $\beta 4$, is negative and significant, which indicates the influence of real manipulation that moderates the relationship between CSR and financial performance. The higher level of real manipulation, the influence of CSR on financial performance worsened the company's financial performance.

\section{The Operational Definition and Measurement of Variables}

The research model consists of four variables, namely the independent variable, moderation, dependent and control. Here is a description of the operational definition and measurement of each variable.

\section{Dependent Variables}

- Corporate Social Responsibility (CSR) 


\section{Rahmawati et al.}

Dependent variable to test the first hypothesis of this study is CSR. CSR is measured by the index of social disclosure as a dummy variable. Social disclosure index was calculated by each company's CSR disclosure, sample was coded 1 if the company revealed the items on the list of questions, and coded 0 if the company does not disclose the item corresponding to the list of questions. Furthermore, the score of each item is summed to obtain a total score for each company, and the total score is weighted by the total score should be in the list of questions. This study uses a reference list of social disclosure by GRI in 2006 to determine the CSR index (Prior et al. 2008).

\section{- Corporate Financial Performance (CFP)}

Dependent variable to test the second hypothesis of this research was the corporate financial performance or financial performance. Financial performance was measured using return on assets (ROA). ROA is the ratio of earnings before interest and taxes to total asset value.

\section{Independent Variable/Moderator}

\section{- Real Activities Manipulation (MAR)}

Real activity manipulation was assessed through Cash Flows Operating activities. Before entering in the hypothesis testing, regression analysis was conducted to find the cash flow to normal operations. Regression models for cash flow from operating activities of normal replicating research according to Roychowdhury (2006) is as follows:

$\mathrm{CFO} t / \mathrm{A} t-1=\alpha 0+\alpha 1(1 / \mathrm{A} t-1)+\beta 1(\mathrm{~S} t / \mathrm{A} t-1)+$ $\beta 2(\Delta \mathrm{S} t / \mathrm{A} t-1)+\epsilon t$
Description:

CFOt/At-1: cash flow operations in year $t$ scaled by total assets in year $t-1$.

$\alpha 1(1 / A t-1)$ : the intercept is scaled by total assets in year $t-1$ with the goal of operating activity cash flow does not have a value of 0 when sales and sales lag is 0 .

St/At-1: sales in year $t$ scaled by total assets in year $t-1$.

$\Delta \mathrm{S} t / \mathrm{A} t-1$ : sales in year $t$ minus sales in year $t-$ 1 scaled by total assets in year $t-1$.

$\alpha 0$ : constants.

$\epsilon t$ : error term in year $t$.

Therefore, in this study abnormal cash flow operations were used, for each observation year abnormal operating activities cash flows (ABN_CFO) is the difference of the value of the actual cash flow operating activities scaled by total assets one year before testing reduced the cash flow normal operations are calculated using the estimated coefficients of the model equation above.

$\mathrm{ABN} \_\mathrm{CFO}=\mathrm{CFO} t-\mathrm{CFO} t / \mathrm{A} t-1$

- Real Activity Manipulation Through Production Costs

Production above the normal level of operating companies (overproduction) in order to report the cost of goods sold (COGS) lower, is one of the ways in which the management manipulate earnings through real activities manipulation. The cost of production is the sum of cost of goods sold (COGS) and change in inventories ( $\triangle \mathrm{INV}$ ) throughout the year. Researchers as 
International Journal of Management, Economics and Social Sciences

Roychowdhury (2006) used the following model to estimate the cost of normal production:

$\mathrm{PROD} t / \mathrm{A} t-1=\alpha 0+\alpha 1(1 / \mathrm{A} t-1)+\beta 1(\mathrm{~S} t / \mathrm{A} t-1$ )$+\beta 2(\Delta \mathrm{S} t / \mathrm{A} t-1)+\beta 3(\Delta \mathrm{S} t-1 / \mathrm{A} t-1)+\epsilon t$

Description:

PRODt/At-1: production costs in year $t$ scaled by total assets in year $t-1$, where PROD $t=$ COGS $t$ $+\Delta \mathrm{INV} t$.

$\alpha(1 / A t-1)$ : the intercept is scaled by total assets in year $t-1$ with the aim that the value of the cost of production does not have a value of 0 when sales and sales lag is 0 .

St/At-1: sales in year $t$ scaled by total assets in year $t-1$

$\Delta S t / A t-1:$ sales in year $t$ minus sales in year $t-1$ scaled by total assets in year $t-1$. $\Delta S t-1 / A t-1:$ change in sales in year $t-1$ scaled by total assets in year $t-1$. $\alpha 0:$ constants

$\epsilon t$ : error term in year $t$.

Similarly, the cash flow operations, the estimated coefficient of the regression equation above is used to calculate the value of the cost of normal production. Thus, abnormal production costs (ABN_PROD) obtained by subtracting the value of the actual production costs are scaled by total assets one year prior to the testing period with normal production costs are calculated using the estimated coefficients of the model equation above.

ABN_PROD $=$ PROD $t-$ PROD $t / A t-1$

\section{- Real Activity Manipulation Through Discretionary Costs}

To calculate the cost of a normal level of discretionary costs, researchers use the following regression model as used by Roychowdhury (2006):

DISEXPt/A $t-1=\alpha 0+\alpha 1(1 / \mathrm{A} t-1)+\beta(\mathrm{S} t$ $1 / A t-1)+\epsilon t$

Description:

DISEXP $t / A t-1$ : discretionary costs in year $t$ scaled by total assets in year $t-1$

$\alpha(1 / A t-1)$ : the intercept is scaled by total assets in year $t-1$ with the goal of discretionary expenses not have a value of 0 when sales and sales lag is 0 .

$S t-1 / A t-1:$ sales in year $t-1$ scaled by total assets in year $t-1$.

Discretionary costs are defined as the sum of the cost of advertising, research and development expenses, selling expenses, and general and administrative expenses. Value of the estimated coefficients of the regression equation above is used to calculate the normal value of discretionary costs. Thus, abnormal discretionary expenses (ABN_DISEXP) obtained by subtracting the actual value of discretionary expenses scaled by total assets one year prior to the testing period with normal discretionary expense calculated using the estimated coefficients of the model equation above.

ABN_DISEXP $=$ DISEXP $t-$ DISEXP $t / A t-1$

\section{- Control Variables}

The research model uses five control variables that have an impact on CSR activities. Control variables used in this study consisted of: 


\section{Rahmawati et al.}

1. Firm size ( SIZE ), according to Prior et al. (2008) there is a positive relationship between firm size and CSR activities and financial performance. Firm size is measured by the logarithm of total assets.

2. Commissioners size (KOM), Coller and Gregory (1992) and Sembiring (2005) explained that the commissioners used to monitor and control the CEO. The greater the number of commissioners, it will be easier to control the CEO and monitoring conducted more effectively. Thus, the greater the commissioners are expected to supervise the CSR activities more effective and aligned with the interests of stakeholders. Board size used in this study is consistent with Juholin (2004) and Sembiring (2005), namely the number of commissioners.

3. Institutional Ownership $(\mathrm{KI})$ is the number of shares held by institutional investors to total shares outstanding. Institutional ownership is measured by the percentage of shares owned by institutional investors of total shares outstanding. According to Bushee (1998) institutional ownership has the ability to reduce the incentives of self-interested managers through intensive supervision level. Institutional ownership may suppress the tendency to utilize discretionary accrual management in the financial statements. This was confirmed by Prior et al. (2008) which proved that the higher the institutional ownership in a company, better the effect on the practice of CSR and corporate financial performance, because the institutional ownership typically have greater power of monitoring than noninstitusional ownership.
4. Leverage (LEV) is a source of corporate finance from third parties, i.e. parties other than the investor company. Leverage is measured by the ratio of total liabilities to total equity. Leverage is used as a control variable to test the second hypotheses is the leverage of the previous period. Leverage the previous period represents a risk that could affect the company's financial performance in the future.

\section{RESULTS AND DISCUSSION}

The regression model used in this study has passed the tests of the classical assumptions, namely multicollinearity, autocorrelation, heteroscedasticity, and normality.

Table 1 (see Appendix- I) presents the descriptive statistics of sample. The results of the descriptive statistics in this table show that the average negative for real activities manipulation and positive cash flow for real activities manipulation of production costs and discretionary costs. These results indicate that manufacturing companies in Indonesia to follow the pattern of earnings management that minimizes the average income is negative and maximize profits if positive average during the period 2006-2008. Manipulation of sales done by delaying the timing of sales and decrease costs of discretionary cash, as well as the production of goods in order to exaggerate the boarding reported lower sales. On average ability to generate profits as measured by return on assets of 15 percent.

The test results of regression Model 1 indicate that the value of the determinant coefficient (adj. 
International Journal of Management, Economics and Social Sciences

$\mathrm{R}$-squared) is $0.125(12.5 \%)$ means that real management did not implement real manipulation manipulation on operation cash flow, on practices proven to improve CSR programs.

production cost, on discretionary expense, and Table 3 shows the value of the determinant

\begin{tabular}{cccc}
\hline Variable & Coefficient & Probabilities $^{* *}$ & Adj.R2 $^{2}$ \\
\hline Constant & 0.344 & $0.001^{* *}$ & \\
MAR1 & 0.036 & 0.570 & \\
MAR2 & -0.003 & 0.727 & 0.125 \\
MAR3 & -0.055 & 0.184 & \\
CFP & 0.408 & $0.003^{* *}$ & \\
$f$-Statistic $=2.656$ & & $0.045^{*}$ & \\
\hline$n=48 ; D V: C S R$ & & \\
${ }^{*}<.05$ & & \\
$p<.01$ & & \\
Where: & & \\
MAR1: Real manipulation on operation cash flow & \\
MAR2: Real manipulation on production cost & \\
MAR3: Real manipulation on discretionary expense \\
CFP $:$ Financial performance
\end{tabular}

Table 2. Result of Regression Test Model 1

financial performance are able to explain 12.5 percent variation in CSR, the rest is explained by other factors. The Analysis of Variance (ANOVA) test results show that the $f$-test value is 2.65 and significant at 5 percent level, means that the regression model is suitable for use as a predictive model for CSR, and it can be said that real manipulation on operation cash flow, on production cost, on discretionary expense, and financial performance jointly influence CSR.

This result explains that real manipulation on operation cash flow, real manipulation on production cost, and real manipulation on discretionary expense has no positive influence on CSR, so this hypothesis is empirically rejected. This indicates that companies that do not implement the real manipulation proved to increase their activity of CSR as an entrenchment strategy. Thus the hypotheses $1 \mathrm{a}, 1 \mathrm{~b}$, and 1c of this study are rejected. In other words, the results of this study provide empirical evidence that coefficient ( $R$-squared) of the test results of regression Model 2 is 55.4 percent which means that real manipulation, CSR, the interaction between real manipulation and CSR, company size, board size, institutional ownership, and leverage can explain 55.4 percent variation in corporate financial performance, the remainder explained by other factors outside the model of this research. ANOVA test results showed that the $f$-test is significant at 1 percent level, meaning that the regression model is suitable for use as a predictive model for corporate financial performance, or it can be said that real manipulation, CSR, the interaction between real manipulation and CSR, the size of the company, board size, institutional ownership, and leverage jointly influence corporate financial performance.

Table 3 indicates that the coefficient of interaction term of real manipulation operation cash flow and CSR is negative and $p$-value is .01. This indicates that the interaction of real 
Rahmawati et al.

manipulation on operation cash flow and CSR is to cover the earnings management practices that negatively related to corporate financial can damage the interests of stakeholders.

performance and empirically supported at the The second hypothesis $\left(\mathrm{H}_{2 b}\right)$ is rejected; it

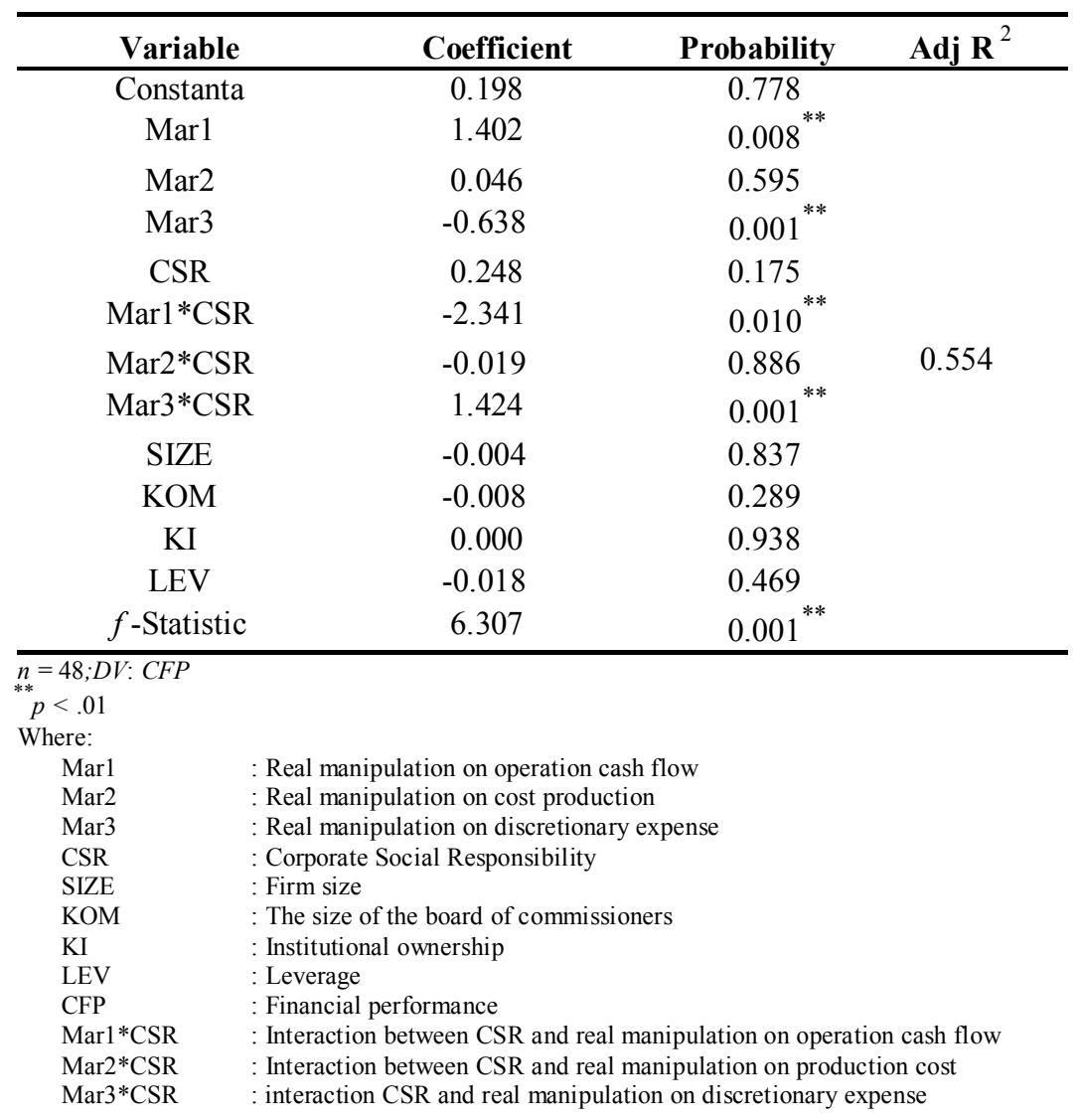

Table 3. Result of Regression Test Model 2

confidence level of 1 percent. Thus, the second hypothesis $\left(\mathrm{H}_{2 \mathrm{a}}\right)$ of this research is supported. These results interpret that the higher level of real manipulation on operation cash flow leads to an increased CSR program which in turn the company's financial performance in the future. The results are consistent with Prior et al. (2008), who reported that higher levels of earnings management affect the CSR negatively as well as the company's financial performance in the future, because the CSR program is used by the management as a form of entrenchment strategy means the interaction of real manipulation variable on production cost and CSR is not significant. The second hypothesis $\left(\mathrm{H}_{2 \mathrm{c}}\right)$ indicates that the interaction of real manipulation variable on discretionary cost and CSR has positive value at the level of 0.001 . This indicates that the interaction of real manipulation on discretionary cost and CSR is positively related to corporate financial performance and empirically supported at the level of 1 percent. Thus, the second hypothesis $\left(\mathrm{H}_{2 \mathrm{c}}\right)$ of this research is not approved because of the sign contradiction. The result is not consistent with Prior et al. (2008), who said 
International Journal of Management, Economics and Social Sciences

that the higher the levels of real manipulation on discretionary cost, the more CSR negatively affect the company's financial performance in the future because the CSR program is used by the management as a form of entrenchment strategy to cover the real manipulation practices that can damage the interests of stakeholders. Prior et al. (2008) also explain that management has two reasons why they do the earnings management as one way to satisfy the interests of stakeholders. First, it is a preventive measure in anticipation of the stakeholders towards earnings management actions that could jeopardize their positions within the company. Second, it is considered as a mean of self-defense that management tends to align the diverse interests of stakeholders.

\section{CONCLUSION}

The purpose of this study was to analyze and obtain empirical evidence about the effect of real manipulation practices of CSR activities. This study also aims to test whether CSR activities are related to real manipulation practices that affect the company's financial performance in the future. The results of this research based on hypothesis testing are the following:

1. The hypotheses $H_{1 a}, H_{1 b}$, and $H_{1 c}$ are rejected by the test, which proves that the practice of real manipulation has no influence on the activity of CSR. However, financial performance variables significantly affect CSR.

2. The hypothesis $\mathrm{H}_{2 \mathrm{a}}$ is accepted through the test, meaning that the interaction activities of CSR associated with real manipulation on operation cash flow practices affect the company's financial performance in the future.

3. In addition, real manipulation variables, CSR, the interaction between real manipulation and CSR, firm size, the size of the board of commissioners, institutional ownership, leverage, and financial performance, significantly together affect the company's financial performance in the future (model fit for interaction model).

\section{IMPLICATIONS}

The results of this study have implications for theory and practice. Implications for the theory supporting the research of Prior et al. (2008), who concluded that the higher the level of real manipulation on operation cash flow is, the CSR negatively affect the company's financial performance in the future because the CSR program is used by management as a form of entrenchment strategy to cover the real manipulation practices that can damage the interests of stakeholders. This is due to management's expectations that real manipulation practice is adopted to align the interests of stakeholders. Real manipulation practice affects performance with moderating CSR programs. However, the implementation of CSR programs, along with real manipulation practices, negatively impacts the company's financial performance because CSR activities require long-term funds. Investors and creditors are expected to exercise careful consideration to the investment decision (the decision to provide loans); especially in manufacturing companies implementing CSR programs. Management is 


\section{Rahmawati et al.}

expected to be more aware of the importance of management of CSR programs for the survival of companies in the future. To that end, management is expected to harmonize the various interests of stakeholders through CSR programs by maximizing the positive impacts and minimizing negative impact of a particular business activity. While, management cannot avoid opportunities for real manipulation on operation cash flow practices in reporting the company's financial performance, but the expected real manipulation actions are not detrimental to the interests of other stakeholders. In the long run the company can enjoy the benefits of CSR programs on the financial performance and in turn can positively influence public in general.

\section{LIMITATIONS AND FUTURE DIRECTIONS}

The results of this research must be interpreted carefully and thoroughly. As for some of the limitations that can be found am ong others are:

1. The relatively limited sample, 27 out of 393 listed companies of the BEI. The limited number of companies was eligible to be studied because a few companies listed on the Indonesia Stock Exchange were exercising consistent CSR activities throughout the study period and were agreed for voluntary CSR disclosure.

2. This research sample was limited to manufacturing companies, so these results cannot be generalized for other industries. Manufacturing companies represent the highest proportion of industries listed on the Indonesia Stock Exchange (JSE).
3. Disclosure of CSR was voluntary so there was no standard rule of the regulator, which can be used as reference to measure CSR index. This raises the subjectivity element in measuring the CSR index.

4. Broad assessment instruments assessed the expression of only a dummy variable that failed to give detail information about the quality of expression, which is needed to well describe each company.

Based on some of the limitations of the study above, in the following are some considerations that need to be considered in developing and expanding this research:

1. For further research, it is recommended to multiply the number of samples and use the data from the most recent annual report to well describe the latest company' s condition.

2. Future studies are expected to conduct research in all industry sectors, not just manufacturing companies for the results obtained to represent all industrial sectors listed in $\mathrm{BEl}$.

3. Future studies should use data with a longer period to obtain a more valid measurement results.

4. Future studies are required to connect CSR to the value of the company.

\section{REFERENCES}

Aupperle, K., Carroll, A. \& Hatfield, J. (1985). An empirical examination of the relationship between corporate social responsibility and profitability. Academy of Management Journal, 28, 446-463.

Abdolmohammadi, M., Kvaal, E. \& J. C. Langli. (2010). Earnings management priorities of private family firms. Centre for Corporate Governance Research, vol. 3.

Andayani, W. (2008). The impact good corporate governance to earnings management with real activity. Prociding of conference at UPN Veteran Yogyakarta: 24-25, October.

Berman, S., Wicks, A., Kotha, S. \& Jones, T. (1999). Does stakeholder orientation matter? The relationship between 
International Journal of Management, Economics and Social Sciences

stakeholder management models and firm financial performance. Academy of Management Journal, 42, 488506.

Bushee, B.J. (1998). "Institutional investor, long term investment, and earnings management". The Accounting Review, 73(3): 67-92.

Bhaumik, S., \& A. Gregoriou. (2010). "Family" ownership, tunneling and earnings management: A review of the literature. Journal of Economic Surveys, 24(4): 705-729.

Bansal, P. (2005). Evolving sustainably: A longitudinal study of corporate sustainable development, Strategic Management Journal, 26, 197-218.

Crocker, K. J. \& J. Slemrod. (2007). The economics of earnings manipulation and managerial compensation. The Rand Journal of Economics, 38(3): 698-713.

Castelo, M. and Lima, L. (2006). Corporate social responsibility and resource-based perspectives. Journal of Business Ethics, 69, 111-132.

Cespa, G. \& Cestone, G. (2007). Corporate social responsibility and managerial entrenchment. Journal of Economics and Management Strategy, 16(3): 741-771.

Clarkson, M. (1994). A risk based model of stakeholder theory. Proceedings of the Second Toronto Conference on Stakeholder Theory. Centre for Corporate Social Performance and Ethics, University of Toronto. Toronto.

Dahlia. \& Siregar. (2008). The impact of Corporate Social Responsibility to performance company. Accounting national symposium, 11.

Dechow, P. M., R. G. Sloan. \& A. P. Sweeny. (1996). Causes and consequences of earnings manipulations: an analysis of firm subject enforcement action by the SEC. Contemporary Accounting Research, 13(1): 1-32.

Donaldson, T. L. \& Preston, L. E. (1995). The stakeholder theory of the corporation: Concepts, evidence, and implications. Academy of Management Review, 20, 6591.

Ewert, R. \& A. Wagenhofer. (2005). Economic effects of tightening accounting standards to restrict earnings management. The Accounting Review, 80(4): 1101-1124.

Fombrun C, Gardberg N. \& Barnett M. (2000). Opportunity platforms and safety nets: Corporate citizenship and reputational risk. Business and Society Review, 105, 85106.

Graham, J. R., Harvey, C. R. \& Rajgopal, S. (2005). The economic implications of corporate financial reporting. Journal of Accounting \& Economics, 40, 3-73.

Gunny, K. (2005). What are the consequences of real earnings management? Working Paper, University of California.

Gunny, K. A. (2010). The relation between earnings management using real activities manipulation and future performance: Evidence from meeting earnings benchmarks. Contemporary Accounting Research, 27(3): 855-888.

Healy, P. M. (1985). The effect of bonus schemes on accounting decisions. Journal of Accounting and Economics, 7, 85-107.

Hillman, A. J. \& Keim, G. D. (2001). Shareholder value, stakeholder management, and social issues: What' $s$ the bottom line? Strategic Management Journal, 22, 125-139.

Jian, M. \& Wong, T. J. (2010). Propping through related party transactions. Review of Accounting Studies, 15, 70-105.

Juholin, E. (2004). For business or the good of all? A finish approach to corporate social responsibility. Corporate Governance, 4(2): 20-31.
Johnson, S., La Porta, R., Lopez-de-Silanes, F. Lopez-deSilanes. \& Shleifer A. (2000). Tunneling. The American Economic Review, 90(2): 22-27.

Jones, T. M. (1995). Instrumental stakeholder theory: A synthesis of ethics and economics. Academy of Management Review, 20, 404-437.

Jaggi, B. \& Tsui, J. (2007). Insider trading, earnings management and corporate governance: Empirical evidence based on Hong Kong firms. Journal if International Financial Management and Accounting, 18 (3): 192-222.

Luoma, P. \& Goodstein, J. (1999). Stakeholders and corporate boards: Institutional influences on board composition and structure. Academy of Management Journal, 42, 553-563.

Leuz, C., Nanda, D. \& Wysocki, P. D. (2003). Earnings management and investor protection: An international comparison. Journal of Financial Economics, 69, 505527.

Luo, J., Wan, D. \& Cai, D. (2012). The private benefits of control in Chinese listed firms: Do cash flow rights always reduce controlling shareholders ' tunneling? Asia pacific Journal Management, 29, 499-518.

Mulford, C. \& Comiskey, E. (2002). The Financial Numbers Game Detecting Creative Accounting Theory. New York: John Wiley and Sons.

McNichols, M. F. \& Stubben, S. R. (2008). Does earnings management affect firms' investment decisions? The Accounting Review, 83(6): 1571-1603.

McWilliams, A., Siegel, D. S. \& Wright, P. M. (2006). Corporate social responsibility: Strategic implications. Journal of Management Studies, 43, 1-18.

Orlitzky, M., Schmidt, F. L. \& Rynes, S. L. (2003). Corporate social and financial performance: A meta-analysis. Organization Studies, 24, 403-441.

Prencipe, A., Markarian, G. \& Pozza, L. (2008). Earnings management in family firms: Evidence from R\&D cost capitalization in Italy. family Business Review, 21(1): 7188.

Pagano, M. \& Volpin, P. (2005). Managers, workers, and corporate control. The Journal of Finance, 60, 841-868.

Preston, L. \& O' Bannon, D. (1997). The Corporate socialfinancial performance relationship. A typology and analysis. Business and Society, 36, 419-29.

Prior, D., Surroca, J. \& Tribo. (2008). Are socially responsible managers really ethical? Exploring the relationship between earnings management and corporate social responsibility. Corporate Governance: An International Review, 16, 160177.

Roychowdury (2006). Earnings management through real activities manipulation. Journal of Accounting and Economics, 42, 335-370.

Rowley, T. \& Berman, S. (2000). A brand new brand of corporate social performance, Business and Society, 39, 397-418.

Saputro, J.A. \& Setiawati, L. (2004). Growth opportunities and earnings management: Test for political cost hyphotesis. Journal of research and accounting Indonesia vol. 7 no. 2 Mei.

Sembiring, E. (2005). The characteristic of company and corporate social responsibility disclosure: Empirical study at company listed in Indonesia stock exchange. Paper presented at the Accounting national Symposium 8, Universitas Negeri Sebelas Maret, Solo.

Scott. (2011). Financial accounting theory. Prentice Hall Canada. 


\section{Rahmawati et al.}

Saanoun, I., Ben, Y., Riahi, \& Arab, M. B. (2013). Private benefits of control and earnings management: The case of french listed companies. European Journal of Business and Social Sciences, 2(3): 121-139.

Thomas, W. B., Herrmann, D. R. \& Inoue, T. (2004). Earnings management through affiliated transactions. Journal of International Accounting Research, 3(2): 1-25.

Wright, C. J., Shaw, J. R. \& Guan, L. (2006). Corporate governance and investor protection: Earnings management in the U.K and U.S. Journal of International Accounting research, 5(1): 25-40.

Waddock, S. A. \& Graves, S. B. (1997). The corporate social performance-financial performance link. Strategic Management Journal, 18, 303-319.

Watts, R. L. \& Zimmerman, J. L. (1986). Positive accounting theory. Englewood Cliffs, NJ: Prentice Hall.

Zahra, Priem \& Rasheed. (2005). Antecedents and consequences of top management fraud. Journal of Management, 31, 803-828.

\section{ACKNOWLEDGEMENT}

This research has been funded by Economics

Faculty of Sebelas Maret University, Indonesia and has been presented at APEA 2013 Osaka University, Japan. 
International Journal of Management, Economics and Social Sciences

Appendix-I

\begin{tabular}{|c|c|c|c|c|}
\hline & Minimum & Maximum & Mean & Std. Deviation \\
\hline ABN_CFO & -2.94 & .61 & $-1.08 \mathrm{E}-1$ & .72 \\
\hline ABN_PROD & -2.45 & $2.02 \mathrm{E} 1$ & .90 & 4.27 \\
\hline ABN_DISEXP & -3.12 & 1.660 & .029 & .88 \\
\hline CSRt & .436 & .782 & .60 & .10 \\
\hline KOM & 3 & 10 & 5.38 & 2.37 \\
\hline KI & 50 & 95 & 72.95 & 13.25 \\
\hline $\mathbf{K P}$ & 5 & 50 & 26.99 & 13.29 \\
\hline LEV & 1 & 4 & 2.05 & .587 \\
\hline CFP & 0 & 1 & .15 & .123 \\
\hline $\begin{array}{l}n=48 \\
\text { Where: }\end{array}$ & & & & \\
\hline $\begin{array}{l}\text { ABN_CFO } \\
\text { ABN_PROD } \\
\text { ABN_DISEXP } \\
\text { CSR } t \\
\text { SIZE } \\
\text { KOM } \\
\text { KI } \\
\text { KP } \\
\text { LEV } \\
\text { CFP }\end{array}$ & $\begin{array}{l}\text { Real manipulat } \\
\text { Real manipulat } \\
\text { Real manipulat } \\
\text { Corporate Soci } \\
\text { Firm size } \\
\text { The size of the } \\
\text { Institutional ow } \\
\text { Ownership con } \\
\text { Leverage } \\
\text { Financial perfo }\end{array}$ & $\begin{array}{l}\text { on operation cas } \\
\text { on production ce } \\
\text { on discretionary } \\
\text { esponsibility } \\
\text { rd of commissio } \\
\text { ship } \\
\text { tration } \\
\text { nce }\end{array}$ & ense & \\
\hline
\end{tabular}

Table 1. Descriptive Statistics 